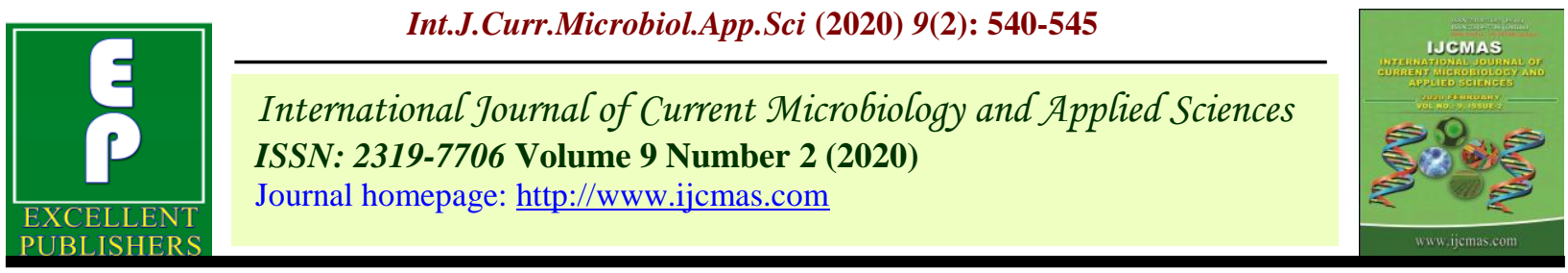

Original Research Article

https://doi.org/10.20546/ijcmas.2020.902.067

\title{
Brand Preferences and Factors Influencing for Purchase of Branded Ready-To-Eat Food Products in Belgaum City of Karnataka State, India
}

\author{
G. B. Chaitra ${ }^{*}$ and N. M. Kerur ${ }^{2}$ \\ ${ }^{1}$ Malwa College, Bathinda, Affiliated to Punjabi University, Patiala, Punjab - 151001, India \\ ${ }^{2}$ Department of Agribusiness Management, College of Agriculture, University of Agricultural \\ Sciences, Dharwad, Karnataka - 580 005, India \\ *Corresponding author
}

\begin{tabular}{|l|}
\hline Ke y w o r d s \\
Consumer \\
behaviour, \\
Marketing, Brand \\
preference and \\
ready-to-eat \\
products
\end{tabular}

\section{A B S T R A C T}

Consumer behaviour in the purchasing of ready-to-eat products is very necessary to judge for the success of getting the right product. The raising urbanization, increasing middleclass population, increasing disposable income of middle-class population and changing taste preferences of Indian consumers may be attributed towards the raising demand of ready-to-eat food market. The present study is aimed to analyse the brand preference and factors influencing for purchase of ready-to-eat food products in Belgaum city of Karnataka state. Convenience sampling method was adopted to collect the data from the respondents. The study revealed that Good Day brand in biscuits and Big Bread among breads were the most popular and preferred brands among the majority of the respondents. Bingo was the most popular brand in chips followed by Lays and Haldirams, and MTR was most popular and preferred brand among maximum number of respondents in pickles followed by Mother's receipe and More Choice. Maximum number of the respondents preferred Maaza brand (mean score of 71.93), followed by Frooti (mean score of 62.08) and Appy (mean score of 54.89). In case of fruit jam that, maximum number of the respondents preferred Kissan jam brand (mean score of 70.80), this was the oldest and most familiar brand among the respondents. Maximum number of respondents given first preference to Amul brand among the milk products. In case of kunda maximum number of respondents preferred Purohith brand because this was the only one brand which is very old and famous for its taste and quality in the study area. Brand loyalty was an important factor in preferring the ready to eat food products. Any firm entering this segment should study these things. The quality offered by the company, taste along with competitive price might lead to brand switching.

\section{Introduction}

Consumer behaviour in the marketing of ready-to-eat products is very necessary to judge for the success of purchase of the right product. The Indian ready-to-eat food market is expected to reach $\$ 647$ million by 2023 (Business Wire report). The raising urbanization, increasing middle-class population, increasing disposable income of middle-class population and changing taste preferences of Indian consumers may be attributed towards the raising demand of ready-to-eat food market.

In today's world of cutthroat fierce 
competition, customer satisfaction is very essential not only remain but also to excel in the given market environment. Today's market is enormously more complex in view of the very market structure. Along with maximizing profit, the companies also need to satisfy their customers for surviving in the present day's competition. Hence, the customer satisfaction has become the ultimate aim of any business concern. Merely selling the product should not alone be the objective of the business it is more to do with customer relationship.

The demand for the ready to eat food products is increasing especially in metros where both husband and wife are usually working. Also, the easy availability and longer shelf life of ready to eat food products is further pushing their demand throughout the country.

Without understanding the desires and needs of consumers, it becomes difficult for marketers to make effective sales. It becomes crucial for marketers to collect as much information as possible from the consumers about their changing tastes and preferences towards different products, so that they can take a proper decision about the designing products according to the consumers expectations.

\section{Materials and Methods}

This study is undertaken in Belgaum city of Karnataka state. Questionnaire was used to collect the primary data from 160 respondents. Convenience sampling method was adopted to collect the data from the respondents. The data was collected only from respondents using ready to eat food products. Garret ranking method was used to analyze the data collected

Per cent position $=100\left(\mathrm{R}_{\mathrm{ij}}-0.5\right) / \mathrm{N}_{\mathrm{j}}$. Where, $R_{i j}$ stands for rank given for the $i^{\text {th }}$ factor by the $\mathrm{j}^{\text {th }}$ individual.

$\mathrm{N}_{\mathrm{j}}$ stands for number of factors ranked by $\mathrm{j}^{\text {th }}$ individual.

\section{Results and Discussion}

It could be inferred from table no.1 that, Biscuit brand-1 brand in biscuits and Bread brand-1 were the most popular and preferred brands among the majority of the respondents. Since it is a new brand in biscuits and it is continuously rendering a very good quality product, it is highly acceptable by the consumers. In addition, comparatively, the price of this brand is low .In case of bread it was known for its brand image, taste and for its quality. In accordance with this result, Padmanabhan and shankaranarayanan (1999) study on brand loyalty revealed that only when price of the particular brand is comparatively lower to prices of other brand in the market the consumers will be brand loyal. The consumers would naturally prefer to low priced brand and they would naturally continue to purchase the same brand as long as the price and quality of the brand is unaltered. Any violation to this would lead to brand switching. Biscuit brand-2 and Biscuit brand-3 biscuits were also popular among the respondents.

It could be seen from the table no. 2 that, Chips brand-1 was the most popular brand in chips followed by Chips brand-2 and Chips brand-3, and brand-1 was most popular and preferred brand among maximum number of respondents in pickles followed by Mother's receipe and More Choice. It may be because of its taste, flavour and quality of the product. In brand preference is influenced by the advertisement strategy adopted by the company. The brand preference is also strengthened by the promotional strategies adopted by the company will also play a crucial role in the minds of the customer.

It could be inferred from table no. 3 that, maximum number of the respondents preferred Soft drinks brand -1 brand (mean score of 71.93), followed by Soft drinks brand -2 (mean score of 62.08) and Soft drinks 
brand -3 (mean score of 54.89). These are the commonly available brands in the study area. Another interesting thing to note here that top two brands in the order of preference had mango as the base material. The taste acquaintance of the people to mango might have prompted them to prefer these brands. In case of fruit jam that, maximum number of the respondents preferred Jam brand -1 jam brand (mean score of 70.80), this was the oldest and most familiar brand among the respondents.

It was noticed from the table 4 that, maximum number of respondents given first preference to Ice creams brand -1 brand. Ice creams brand -1 is one of the well-known brands for milk products in the country and so also in the study area. The Ice creams brand -1 is known for quality products and hence, it is very much popular among the consumers all over the country.

The promotional strategies adopted by Ice creams brand -1 , Ice creams brand -2 and PICKLE BRAND-1 brands might have made them top three preferred brands. Many a times brand name established in some other product of the same brand would also influence the brand preference for the given product. In case of kunda maximum number of respondents preferred Kunda brand -1 brand because this was the only one brand which is very old and famous for its taste and quality in the study area.

Table 5 state that the factors influencing brand preference. While, preferring a particular brand in biscuits, quality was considered as the foremost factor (mean score of 79.93). While preferring a particular brand in bread freshness was considered as the foremost factor (mean score of 85.00). While in case of chips, pickles, fruits juice, ice cream, and kunda taste was considered as the foremost factor in all the products (mean score of $80.56,82.93,79.06,83.43$ and 80.06 respectively). But in case of fruit jam quality was the foremost factor (mean score of 81.31), because in some other brands the keeping quality of the product is less, taste is also not satisfied and also some consumers responded that after some time the jam will become little watery.

The results of the study are in line with the study undertaken by Sheeja (1998) in Coimbatore district of Tamil Nadu inferred that the consumers had considered the quality aspects like aroma, taste, freshness and purity as the major factors which influenced the preference for a particular brand of processed spices. Similarly, the study conducted by Nandagopal and Chinnaiyan (2003) on the brand preference of soft drinks in rural Tamil Nadu revealed that the deciding factors of brand preference were product quality followed by the retail price. The factors that influenced brand preference of biscuits were quality, taste and quantity. In case of bread factors influenced brand preference was freshness, quality and taste. In case of chips, pickles, fruit juice, ice creams and kundathe major factors influenced brand preference were taste and quality. In case of fruit jam taste and quality.

The study was conducted on an elite group of respondents, who were the residents of Belgaum city. Taste of the product will definitely be the prime factor for preference to a brand and quality would become secondary for an elite group.

It does not mean that all other factors like quantity, brand image, advertisements, packing design, offers etc. would not have any influence on brand preference. These factors coupled with the above three prime factors would influence the brand preference. 
Table.1 Brand preference for cereal based ready-to-eat products by consumers in Belgaum city

\begin{tabular}{|c|l|c|c|}
\hline $\begin{array}{c}\text { Sl. No. } \\
\text { Biscuits }\end{array}$ & Brand names & Mean Score & Ranking \\
\hline $\mathbf{1}$ & Biscuit brand-1 & 78.94 & I \\
\hline $\mathbf{2}$ & Biscuit brand-2 & 74.84 & II \\
\hline $\mathbf{3}$ & Biscuit brand-3 & 72.96 & III \\
\hline $\mathbf{4}$ & Biscuit brand-4 & 59.66 & IV \\
\hline $\mathbf{5}$ & Biscuit brand-5 & 59.51 & V \\
\hline $\mathbf{6}$ & Biscuit brand-6 & 54.46 & VI \\
\hline $\mathbf{7}$ & Biscuit brand-7 & 53.98 & VII \\
\hline $\mathbf{8}$ & Biscuit brand-8 & 51.09 & VIII \\
\hline $\mathbf{9}$ & Biscuit brand-9 & 47.58 & IX \\
\hline $\mathbf{1 0}$ & Biscuit brand-9 & 36.50 & X \\
\hline $\mathbf{1 1}$ & Biscuit brand-10 & 32.08 & XI \\
\hline $\mathbf{1 2}$ & Biscuit brand-11 & 30.43 & XII \\
\hline $\mathbf{1 3}$ & Biscuit brand-12 & 27.96 & XIII \\
\hline $\mathbf{1 4}$ & Biscuit brand-13 & 27.14 & XIV \\
\hline Bread & & & I \\
\hline $\mathbf{1}$ & Bread brand-1 & 71.47 & II \\
\hline $\mathbf{2}$ & Bread brand-2 & 66.88 & III \\
\hline $\mathbf{3}$ & Bread brand-3 & 54.21 & IV \\
\hline $\mathbf{4}$ & Bread brand-4 & 44.59 & V \\
\hline $\mathbf{5}$ & Bread brand-5 & 38.50 & VI \\
\hline $\mathbf{6}$ & Bread brand-6 & 26.33 & \\
\hline & & & \\
\hline
\end{tabular}

Table.2 Brand preference for vegetable based ready-to-eat products by consumers in Belgaum city

\begin{tabular}{|c|l|c|c|}
\hline Sl. No. & \multicolumn{1}{|c|}{ Brand names } & Mean Score & Ranking \\
\hline Chips & & & I \\
\hline $\mathbf{1}$ & Chips brand-1 & 67.93 & II \\
\hline $\mathbf{2}$ & Chips brand-2 & 65.34 & III \\
\hline $\mathbf{3}$ & Chips brand-3 & 53.71 & IV \\
\hline $\mathbf{4}$ & Chips brand-4 & 33.34 & V \\
\hline $\mathbf{5}$ & Chips brand-5 & 31.65 & VI \\
\hline $\mathbf{6}$ & Chips brand-6 & 27.56 & I \\
\hline Pickles & & & II \\
\hline $\mathbf{1}$ & Pickle brand-1 & 71.88 & III \\
\hline $\mathbf{2}$ & Pickle brand-2 & 57.25 & IV \\
\hline $\mathbf{3}$ & Pickle brand-3 & 53.31 & V \\
\hline $\mathbf{4}$ & Pickle brand-4 & 45.20 & VI \\
\hline $\mathbf{5}$ & Pickle brand-5 & 43.15 & 32.20 \\
\hline $\mathbf{6}$ & Pickle brand-6 & & \\
\hline
\end{tabular}


Table.3 Brand preference for fruit based products by consumers in Belgaum city

\begin{tabular}{|c|l|c|c|}
\hline \multicolumn{2}{|c|}{ Sl. No. } & \multicolumn{1}{|c|}{ Brand names } & Ranking \\
\hline Fruit juice & & 71.93 & I \\
\hline $\mathbf{1}$ & Soft drinks brand -1 & 62.08 & II \\
\hline $\mathbf{2}$ & Soft drinks brand -2 & 54.89 & III \\
\hline $\mathbf{3}$ & Soft drinks brand -3 & 52.43 & IV \\
\hline $\mathbf{4}$ & Soft drinks brand -4 & 45.52 & V \\
\hline $\mathbf{5}$ & Soft drinks brand -5 & 41.68 & VI \\
\hline $\mathbf{6}$ & Soft drinks brand -6 & 24.43 & VII \\
\hline $\mathbf{7}$ & Soft drinks brand -7 & & I \\
\hline Fruit jam & & 70.80 & II \\
\hline $\mathbf{1}$ & Jam brand -1 & 48.64 & III \\
\hline $\mathbf{2}$ & Jam brand -2 & 47.63 & IV \\
\hline $\mathbf{3}$ & Jam brand -3 & 35.00 & \\
\hline $\mathbf{4}$ & Jam brand -4 & & \\
\hline
\end{tabular}

Table.4 Brand preference for milk based products by consumers in Belgaum city

\begin{tabular}{|c|c|c|c|}
\hline Sl. No. & Brand names & Mean Score & Ranking \\
\hline \multicolumn{4}{|c|}{ Ice creams } \\
\hline 1 & Ice creams brand -1 & 77.77 & I \\
\hline 2 & Ice creams brand -2 & 72.22 & II \\
\hline 3 & Ice creams brand -3 & 59.07 & III \\
\hline 4 & Ice creams brand -4 & 56.06 & IV \\
\hline 5 & Ice creams brand -5 & 46.73 & V \\
\hline 6 & Ice creams brand -6 & 42.31 & VI \\
\hline 7 & Ice creams brand -7 & 39.35 & VII \\
\hline 8 & Ice creams brand -8 & 31.35 & VIII \\
\hline 9 & Ice creams brand -9 & 27.10 & IX \\
\hline \multicolumn{4}{|l|}{ Kunda } \\
\hline 1 & Kunda brand -1 & 70.01 & I \\
\hline 2 & Kunda brand -2 & 65.25 & II \\
\hline 3 & Kunda brand -3 & 58.69 & III \\
\hline 4 & Kunda brand -4 & 40.38 & IV \\
\hline
\end{tabular}

It could be inferred that, Biscuit brand-1 brand in biscuits and Bread brand-1 were the most popular and preferred brands among the majority of the respondents. Chips brand-1 was the most popular brand in chips followed by Chips brand-2 and Chips brand-3, and
Pickle Brand-1 was most popular and preferred brand among maximum number of respondents in pickles followed by Mother's receipe and More Choice. Maximum number of the respondents preferred Soft drinks brand -1 brand (mean score of 71.93), followed by 
Soft drinks brand -2 (mean score of 62.08) and Soft drinks brand -3 (mean score of 54.89). In case of fruit jam that, maximum number of the respondents preferred Jam brand -1 jam brand (mean score of 70.80), this was the oldest and most familiar brand among the respondents. Maximum number of respondents given first preference to Ice creams brand -1 brand among the milk products followed by Ice creams brand -2 and Pickle Brand-1 brands and it might due to the promotional strategies adopted by the companies. In case of kunda maximum number of respondents preferred Kunda brand -1 brand because this was the only one brand which is very old and famous for its taste and quality in the study area. While, preferring a particular brand in biscuits, quality was considered as the foremost factor (mean score of 79.93). While preferring a particular brand in bread freshness was considered as the foremost factor (mean score of 85.00). Brand loyalty was an important factor in preferring the ready to eat food products. Any firm entering this segment should study these things. The quality offered by the company, taste along with competitive price might lead to brand switching.

\section{References}

Bansal N. K., Patel, P. K. and Patil Chidanand, Study on consumer behaviour of the farmers and market potential of hybrid castor seeds in Banaskantha district of Gujarat state, International Journal of Commerce and Business Management, 6 (1), 18-22.

Gupta Manish, 2013, a study of brand preference and consumption pattern of beer in Bareilly. Ind. J. Mktg., 43 (5): 34-47.

Nandagopal, R. and Chinnaiyan, P., 2003, Brand preference of soft drinks in rural Tamil Nadu. Ind. J. Mktg, 33 (1): 14-17.

Padmanaban, N.R. and Sankaranarayanan, K., 1999, Business experience, product lines of dealers and farmers loyalty to dealer for pesticides in southern Tamil Nadu. Ind. J. Agric. Mktg, 13 (3): 6974.

Sheeja, A., 1998, An analysis of consumer buying behaviour towards processed spices. M.Sc. (Agri.) Thesis, Tamil Nadu Agric. Univ., Coimbatore.

https://www.businesswire.com/news/home/20 190411005450/en/Indias-Ready-To-

Eat-Food-Market-2023-AnticipatingCAGR.

\section{How to cite this article:}

Chaitra, G. B. and Kerur, N. M. 2020. Brand Preferences and Factors Influencing for Purchase of Branded Ready-To-Eat Food Products in Belgaum City of Karnataka State, India. Int.J.Curr.Microbiol.App.Sci. 9(02): 540-545. doi: https://doi.org/10.20546/ijcmas.2020.902.067 